\title{
Strategy for Used Fuel Acquisition
}

Steven C. Marschman Chris Rusch

September 2013

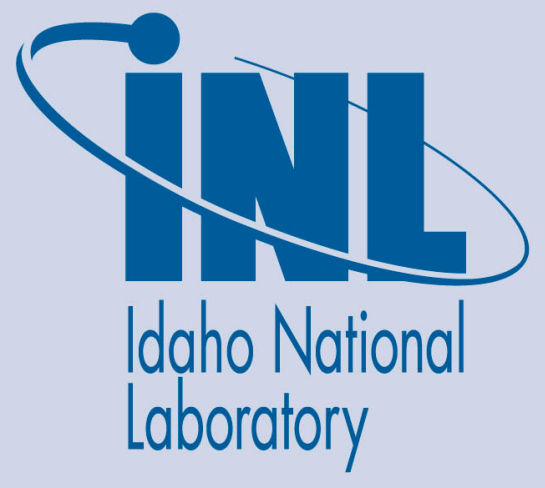

The INL is a U.S. Department of Energy National Laboratory operated by Battelle Energy Alliance 
INL/EXT-13-30174

FCRD-UFD-2013-000335

\title{
Strategy for Used Fuel Acquisition
}

Steven C. Marschman

Chris Rusch ${ }^{1}$

${ }^{1}$ NAC International, Inc.

September 2013

\author{
Idaho National Laboratory \\ Fuel Cycle Research \& Development \\ Idaho Falls, Idaho 83415
}

http://www.inl.gov

Prepared for the

U.S. Department of Energy

Office of Nuclear Energy

Under DOE Idaho Operations Office

Contract DE-AC07-05ID14517 


\section{DISCLAIMER}

This information was prepared as an account of work sponsored by an agency of the U.S. Government. Neither the U.S. Government nor any agency thereof, nor any of their employees, makes any warranty, expressed or implied, or assumes any legal liability or responsibility for the accuracy, completeness, or usefulness, of any information, apparatus, product, or process disclosed, or represents that its use would not infringe privately owned rights. References herein to any specific commercial product, process, or service by trade name, trade mark, manufacturer, or otherwise, does not necessarily constitute or imply its endorsement, recommendation, or favoring by the U.S. Government or any agency thereof. The views and opinions of authors expressed herein do not necessarily state or reflect those of the U.S. Government or any agency thereof. 
This page intentionally left blank. 


\section{Strategy for Used Fuel Acquisition}

FCRD-UFD-2013-00335

INL/EXT-13-30174

\section{Revision 0}

September 12, 2013

Approved by:

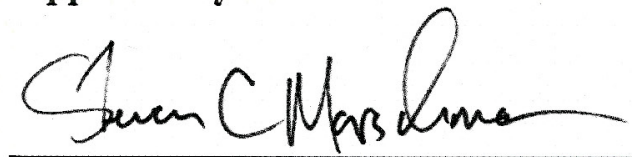

Steven C. Marschman

Project Manager, Field Demonstration

Storage and Transportation, Used Fuel Disposition

Reviewed by:

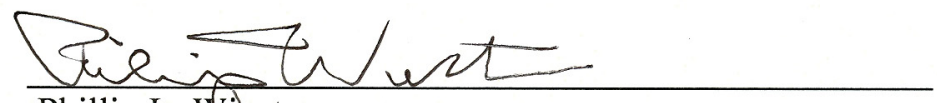

Phillip L. Winston
September 13, 2013

Date
September 13, 2013

Date 
This page intentionally left blank. 


\section{SUMMARY}

This report fulfills the M3 milestone, M3FT-13IN08020612- Data Needs from Full-Scale Demonstration, under Work Package Number FT-13IN080202.

The U.S. Department of Energy Office of Nuclear Energy (DOE-NE), Office of Fuel Cycle Technology, has established the Used Fuel Disposition Campaign (UFDC) to conduct the research and development activities related to storage, transportation, and disposal of used nuclear fuel and high-level radioactive waste. The mission of the UFDC is to identify alternatives and conduct scientific research and technology development to enable storage, transportation and disposal of used nuclear fuel (UNF) and wastes generated by existing and future nuclear fuel cycles. The UFDC Storage and Transportation staffs are responsible for addressing issues regarding the extended or long-term storage of UNF and its subsequent transportation. The near-term objectives of the Storage and Transportation task are to use a science-based approach to develop the technical bases to support the continued safe and secure storage of UNF for extended periods, subsequent retrieval, and transportation.

While both wet and dry storage have been shown to be safe options for storing UNF, the focus of the program is on dry storage at reactor or centralized locations. Because limited information is available on the properties of high burnup fuel (exceeding 45 gigawatt-days per metric tonne of uranium [GWd/MTU]), and because much of the fuel currently discharged from today's reactors exceeds this burnup threshold, a particular emphasis of this program is on high burnup fuels.

Since high burnup used fuels have only been loaded into dry storage systems in the past decade or so, these materials are available to the UFDC for testing in only very limited quantities. Much of what is available has come via NRC testing programs. Some of the fuels that have achieved "high burnup," were of conventional design (e.g. lower enrichments, smaller plenum spaces, extra reactor cycles). The handling and transfer of these materials from utility to laboratory has not always been prototypical of how used nuclear fuel is prepared for dry storage; research fuels have not been subjected to the same vacuum drying conditions that can lead to changes in hydride morphology that will affect the mechanical properties of the fuel.

To produce defensible data, HBU fuel for R\&D purposes must be handled in a manner consistent with how fuel is readied for dry storage in the commercial industry. This report documents what types of fuel are of interest to the campaign, and how those fuels could be acquired and shipped to the Idaho National Laboratory (INL) for incorporation into the campaign R\&D mission. It also identifies any gaps in INL capabilities that might preclude working with one fuel type or another. 


\section{CONTENTS}

SUMMARY V

ACRONYMS viii

Strategy for Used Fuel Acquisition .1

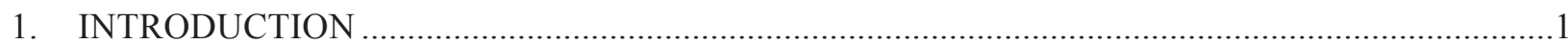

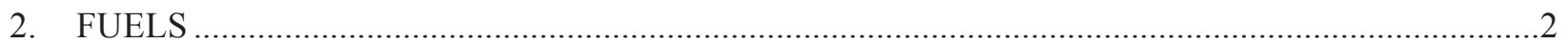

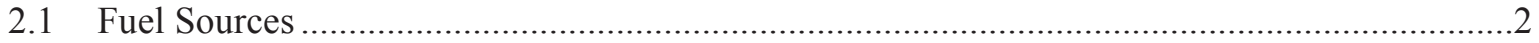

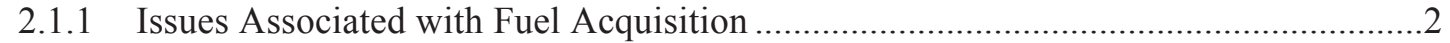

2.1.2 Potential Sources of HBU UNF from U.S BWRs and PWRs ……...........................

2.1.3 Potential Sources of HBU UNF from Foreign BWRs and PWRs..............................4

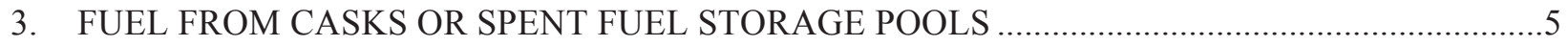

3.1 Casks from Independent Spent Fuel Storage Installations (ISFSIS) ......................................

3.1.1 Fuel from Dry Storage Casks ..............................................................................

3.1.2 Fuel from the HBU Dry Storage Demonstration Project Cask .....................................

3.1.3 Summary of Fuel Acquisition from Dry Storage Casks .............................................

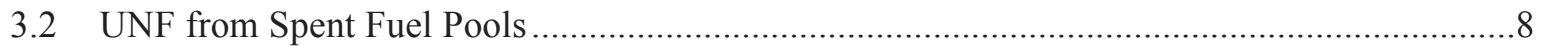

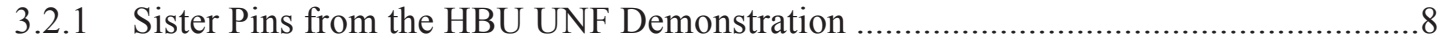

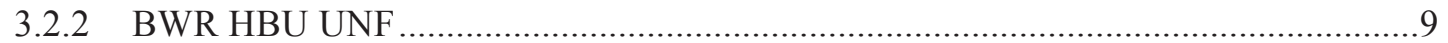

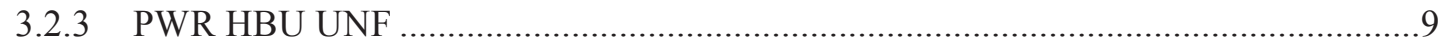

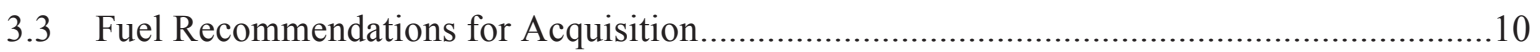

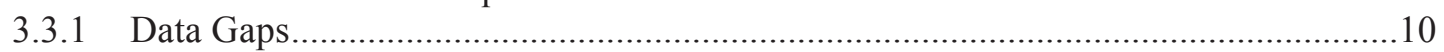

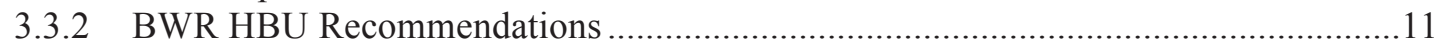

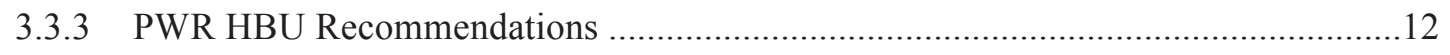

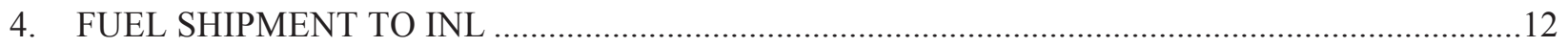

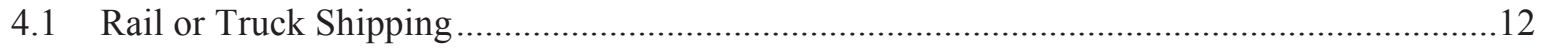

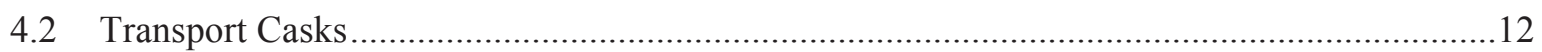

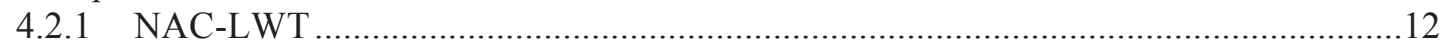

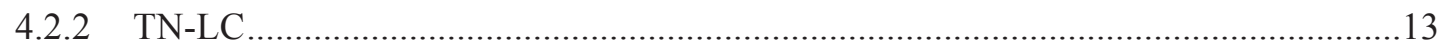

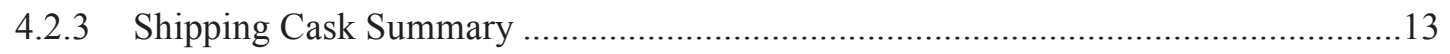

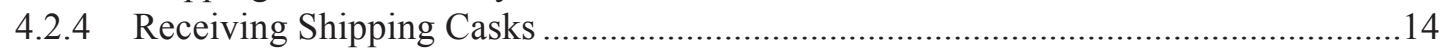

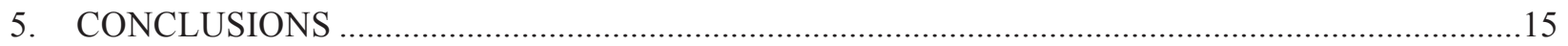

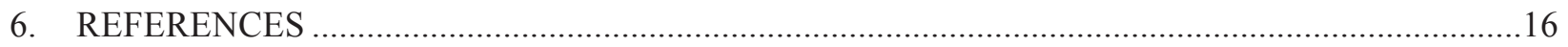

\section{TABLES}

Table 2-1. High Burnup Used Nuclear Fuel from U.S. BWRs............................................................ 4

Table 2-2. High Burnup Used Nuclear Fuel from U.S. PWRs............................................................. 4

Table 2-3. High Burnup Used Nuclear Fuel from Foreign BWRs and PWRs ........................................ 5 
This page intentionally left blank. 


\section{ACRONYMS}

BWR boiling water reactor

CFA Central Facilities Area

HFEF Hot Fuels Examination Facility

INL Idaho National Laboratory

INTEC Idaho Nuclear Technology and Engineering Center

ISFSI Independent Spent Fuel Storage Installation

MFC Materials and Fuels Complex

NAC-LWT NAC International, Inc. Legal Weight Truck

ORNL Oak Ridge National Laboratory

PNNL Pacific Northwest National Laboratory

PWR pressurized water reactor

SET separate effects test

SSC Structures, Systems, and Components

SST small-scale test

TN TransNuclear, Inc.

TN-LC TransNuclear, Inc. Long Cask

UFDC used fuel disposition campaign

UNF used nuclear fuel 
This page intentionally left blank. 


\section{Strategy for Used Fuel Acquisition \\ 1. INTRODUCTION}

The purpose of this report is to recommend used fuels that might be acquired to support of the Used Fuel Disposition Campaign, Storage and Transportation research and development (R\&D) program. While there are many variations of fuel types and irradiation histories, the program cannot possibly acquire and test every variation. The program is challenged with bounding this nation's inventory of UNF to ensure those materials can be safely transported and handled at the end of an extended dry storage period. Because limited information is available on the properties of high burnup fuel (exceeding $45 \mathrm{GWd} / \mathrm{MTU}$ ), and because much of the fuel currently discharged from today's reactors exceeds this burnup threshold, a particular emphasis of this program is on high burnup fuels.

Until a disposition pathway for used nuclear fuel (recycling or geologic disposal), is chosen and implemented, the storage periods for UNF will likely be longer than originally intended. The ability of the important-to-safety structures, systems, and components (SSCs) to continue to meet safety functions over extended times must be determined and demonstrated. In addition, the ability of these SSCs to meet applicable safety functions when the used nuclear fuel is transported must be ensured. To facilitate all options for disposition and to maintain retrievability and normal back-end operations, it is considered an important objective of this program to evaluate the likelihood that the used nuclear fuel remains undamaged after extended storage.

The UFDC has issued Gap Analysis to Support Extended Storage of Used Nuclear Fuel[1] that documents the initial gap analysis performed to identify data and modeling needs to develop the desired technical bases to enable the extended storage of UNF. For most SSCs important to safety, additional data are required, often because there are limited data on the new materials used in more modern fuels or dry storage cask systems or because the effects of high burnup and extended storage are not fully known. Once identified, the program began to establish the methodologies to close those gaps. For several of these "gap closure strategies," a test material must be acquired for use in the strategy's R\&D efforts.

The analysis identified several gaps which require data from UNF samples can provide useful information. These gaps are:

- Subcriticality (burnup credit and moderator exclusion) - radionuclide inventory in fuel rods

- Stress profiles - mechanical strength of the fuel rod

- Fuel Transfer Options - ensure fuel is handled in a prototypic manner

- Cladding - annealing of radiation damage

- Cladding $-\mathrm{H}_{2}$ effects, reorientation and embrittlement

- Cladding $-\mathrm{H}_{2}$ effects, delayed hydride cracking

- Cladding - oxidation

- Cladding - creep

- Fuel Assembly Hardware - stress corrosion cracking (SCC) of lifting hardware and spacer grids

The data needed to close these gaps will help guide what types of fuel should be acquired by the program. 


\section{FUELS}

High burnup used nuclear fuel is typically identified as those fuels that have attained a burnup of 45 gigawatt-days/metric tonne uranium (GWD/MTU) or higher during irradiation in a nuclear reactor. Achieving these high burnup levels has taken a great deal of research and testing. Nuclear fuels designed for high burnup service vary somewhat between fuel manufacturers.

Light water reactors (LWR) are comprised of pressurized water reactors (PWR) and boiling water reactors (BWR). There are similarities and differences between the fuels used in these reactors as a result of how these two types of reactors are operated.

To achieve high burnup, fuel enrichment is nearing 5\% U-235. Cladding remains zirconium based. PWRs have historically utilized zircaloy-4 cladding; however, as burnups have increased, tubing vendors had introduced alloys that are more oxidation resistant or have improved mechanical properties (e.g. ZIRLOTM ${ }^{2}, \mathrm{M}^{\circledR 3}$ ). BWR fuels are clad in zircaloy-2, but zirconium (or zirconium alloy) liners are often added at the inner surface of the clad to act as a hydrogen getter. To accommodate additional fission gas generation, plenums are being enlarged to maintain acceptable fuel rod internal pressure. Fuel assemblies are also evolving; PWRs are available with fuel configured in $14 \times 14,15 \times 15,16 \times 16,17 \times 17$, or even $18 \times 18$ arrays. BWRs have fuel cells that contain 4 assemblies, and those assemblies have been configured in $7 \mathrm{x} 7,8 \mathrm{x} 8$, 9x9, and 10x10 arrays. Except for the 10x20 array designs, BWR fuels are not typically HBU.

\subsection{Fuel Sources}

The acquisition of HBU UNF is not a simple undertaking. The NRC has acquired some HBU fuel samples that are stored at Oak Ridge National Laboratory (ORNL) and the Babcock \& Wilcox Technical Services Group, Inc. (B\&W TSG) Hot Cell Facility in Lynchburg, Virginia. All other HBU UNF in the U.S. is owned by private utilities. Another source of HBU UNF is from foreign power reactors.

\subsubsection{Issues Associated with Fuel Acquisition}

The NRC inventory of fuels was acquired for use in R\&D activities related to NRC needs. The NRC has stated on several occasions 'it is our job to find if a problem exists, it is the utilities' problem to figure out if the problem is serious and how to mitigate it. Thus, the NRC has acquired some HBU UNF, but that inventory is limited in size and must serve their needs first. The NRC has offered some of their fuel to be tested as part of collaborative R\&D (e.g. mechanical properties testing where both DOE, industry, and the NRC benefit from the work), however, they do not have a sufficient quantity to satisfy the DOE UFD needs. The NRC inventory includes fuels that were part of lead test assemblies and other experiments that were not designed specifically to be high burnup per se. The plenum space may be similar to that of a low burnup fuel design (thus higher internal gas pressure than a typical HBU fuel). Some fuels may have a lower enrichment (e.g. 3.5\% U-235 as opposed to 4.5\%) and thus the fuel was not "contributing" fully to power production at end of life. Still other fuels may have needed extra cycles to achieve the high burnup (e.g. four cycles) as opposed to the standard number of cycles for typical HBU fuels (e.g. three cycles). These fuels still have great value, but they are not truly

\footnotetext{
${ }^{2}$ ZIRLO is a trademark of the Westinghouse Electric Company.

${ }^{3} \mathrm{M} 5$ is registered trademark of AREVA NP
} 
prototypic of HBU UNF.

Most U.S. utilities are now discharging HBU UNF from their reactors. Acquiring fuel for R\&D purposes from utilities is not simple. As a result of the delay in establishing a final disposition path for UNF, many utilities have requested, via legal action, redress for the continued storage of UNF. However, fuel has been provided in the past to R\&D programs that has not resulted in legal actions. The sensitivity of this issue requires that the legal status of any fuel acquired for the UFDC should be clearly established between the fuel's owner, the DOE, and any other affected parties. The recent award of a contract for the purposes of performing a HBU UNF dry storage demonstration provides an opportunity to determine how best to acquire fuel for UFDC R\&D purposes.

This demonstration project will place up to $32 \mathrm{HBU}$ UNF assemblies in a large dry storage cask to obtain confirmatory data regarding the long term storage that fuel. To document the initial condition of the fuel that is placed in that demonstration, "sister" fuel rods will be removed from selected assemblies and sent to a national laboratory for characterization. It is anticipated that up to 25 fuel rods would be acquired for R\&D. If successful, this could open the door for other fuel acquisitions that will support the UFDC R\&D needs.

\subsubsection{Potential Sources of HBU UNF from U.S BWRs and PWRs}

NAC International, Inc. (NAC) was tasked to identify potential sources of BWR and PWR HBU UNF. Reactor operation information was extracted from the Nuclear Energy Institute (NEI) Fuel-Trac database and sorted to compile a spreadsheet ${ }^{4}$ that contained burnup information regarding operating BWRs and PWRs in the U.S. The Fuel-Trac database consists of a nuclear fuel model for every commercial reactor in the world.

Some key aspects regarding the information are as follows:

- Historic burnup information is based on actual generation data and associated capacity factors.

- Modern PWR fuel designs with fuel rods that contain optimized concentrations of iron, niobium and tin would be discharged in large quantities starting around the year 2000 .

- The speadsheet includes cycle startup and shutdown dates so that the heat output of the SNF can be determined if necessary.

- The spreadsheet lists average discharge burnup, meaning maximum assembly or maximum fuel rod burnup will be proportionally higher than the burnup listed.

Based on information from the Burnup Table, Table 2-1 lists some BWRs that have discharged high burnup SNF. Modern 10x10 fuel designs have been deployed in these BWRs.

\footnotetext{
${ }^{4}$ The spreadsheet is not included as part of this report as it is several hundred pages long when printed. It is available upon request.
} 
Table 2-1. High Burnup Used Nuclear Fuel from U.S. BWRs

\begin{tabular}{ccc} 
Operator & Nuclear Plant & $\begin{array}{c}\text { Maximum Batch Discharge Burnup } \\
\text { (MWD/MTU) }\end{array}$ \\
\hline Duke Energy & Brunswick & 52,586 \\
Entergy & Grand Gulf & 52,489 \\
Exelon & Clinton & 52,688 \\
Exelon & Limerick & 54,551 \\
\hline Exelon & Peach Bottom & 49,167 \\
Exelon & Dresden & 50,030 \\
Nebraska PPD & Cooper & 49,105 \\
\hline
\end{tabular}

The next table lists some PWRs that have discharged high burnup SNF based on information from the Burnup Table and also lists the fuel design type.

Table 2-2. High Burnup Used Nuclear Fuel from U.S. PWRs.

\begin{tabular}{|c|c|c|c|}
\hline Operator & Nuclear Plant & Fuel Design Type & $\begin{array}{l}\text { Maximum Batch } \\
\text { Discharge Burnup } \\
\text { (MWD/MTU) }\end{array}$ \\
\hline Dominion Generation & North Anna & Westinghouse $17 \times 17$ & 50,552 \\
\hline Duke Energy & Crystal River & B\&W 15x15 & 54,439 \\
\hline Duke Energy & Robinson & Westinghouse $15 \times 15$ & 54,207 \\
\hline Duke Energy & Shearon Harris & Westinghouse $17 \times 17$ & 50,828 \\
\hline Exelon & 3 Mile Island & B\&W $15 \times 15$ & 54,829 \\
\hline Exelon & Braidwood & Westinghouse $17 \times 17$ & 57,295 \\
\hline Exelon & Byron & Westinghouse $17 \times 17$ & 55,294 \\
\hline First Energy & Beaver Valley & Westinghouse $17 \times 17$ & 55,494 \\
\hline First Energy & Davis Besse & B\&W $15 \times 15$ & 53,861 \\
\hline FPL Group & Point Beach & Westinghouse $14 \times 14$ & 53,872 \\
\hline Northern States Power & Prairie Island & Westinghouse $14 \times 14$ & 55,903 \\
\hline PG\&E & Diablo Canyon & Westinghouse $17 \times 17$ & 52,766 \\
\hline South Carolina E\&G & V.C. Summer & Westinghouse $17 \times 17$ & 53,442 \\
\hline Southern Nuclear ${ }^{\mathrm{b}}$ & Farley & Westinghouse $17 \times 17$ & 56,609 \\
\hline Southern Nuclear ${ }^{b}$ & Vogtle & Westinghouse $17 \times 17$ & 53,544 \\
\hline STP Nuclear & South Texas & Westinghouse $17 \times 17 \mathrm{XL}^{\mathrm{a}}$ & 51,887 \\
\hline TVA & Sequoyah & Westinghouse $17 \times 17$ & 50,719 \\
\hline
\end{tabular}

a. The "XL" designation refers to fuel with a 14-foot active length.

b. Actual burnup information.

\subsubsection{Potential Sources of HBU UNF from Foreign BWRs and PWRs}

The NEI Fuel-Trac database was also examined to determine foreign BWRs and PWRs that have discharged high burnup SNF. Foreign sources may need to be considered if the legal issues surrounding DOE acquiring fuel from U.S. utilities cannot be resolved. Though more expensive to obtain, fuel can be shipped across borders and across oceans if necessary. 
Table 2-3. High Burnup Used Nuclear Fuel from Foreign BWRs and PWRs

\begin{tabular}{|cccccc} 
Country & Operator & Nuclear Plant & $\begin{array}{c}\text { Plant } \\
\text { Type }\end{array}$ & Fuel Design Type & $\begin{array}{c}\text { Maximum Batch } \\
\text { Discharge Burnup } \\
\text { (MWD/MTU) }\end{array}$ \\
\hline Belgium & Synatom & Doel & PWR & Westinghouse 17x17 XL & 55,018 \\
\hline Brazil & Eletronuclear & Angra & PWR & KWU 16x16 & 53,608 \\
\hline Germany & EnKK & Philippsburg & BWR & KWU 10x10 & 51,985 \\
\hline Germany & EnKK & Necker & PWR & $18 \times 18$ & 56,871 \\
\hline Germany & E.On KK & Grohnde & PWR & KWU 16x16 & 51,292 \\
\hline Germany & E.On KK & Isar 2 & PWR & KWU 18x18 & 57,629 \\
\hline Germany & RWE Power & Emsland & PWR & KWU 18x18 & 56,155 \\
\hline Germany & RWE Power & Gundremmingen & BWR & $10 \times 10$ & 52,003 \\
\hline Sweden & Vattenfall & Ringhals & PWR & Westinghouse 17x17 & 53,572 \\
\hline Switzerland & AXPO & Beznau & PWR & Westinghouse 14x14 & 57,620 \\
\hline Switzerland & AXPO & Leibstadt & BWR & $10 \times 10$ & 54,006 \\
\hline Switzerland & BKW & Muehleberg & BWR & $10 \times 10$ & 55,860 \\
\hline Switzerland & KK Goesgen & Goesgen & PWR & KWU 15x15 & 58,333 \\
\hline
\end{tabular}

\section{FUEL FROM CASKS OR SPENT FUEL STORAGE POOLS 3.1 Casks from Independent Spent Fuel Storage Installations (ISFSIS)}

When evaluating sources of fuel to acquire, the desired characteristics must be considered. To obtain fuel for beginning of storage life properties, fuel can be acquired from utility spent fuel pools. If it is desired to obtain fuel that has been aged in dry storage, fuel must be obtained from storage casks/systems or the fuel must be aged either in a full-scale demonstration test ${ }^{5}$ or a "small-scale test."

\subsubsection{Fuel from Dry Storage Casks}

Challenges associated with opening large storage casks at a utility's ISFSI include:

- Having the capability to open the storage system and recover fuel onsite

- Having the capability to ship a large cask/canister to another site for opening and recovering fuel

UNF is stored in one of two ways; as metal canisters stored in a concrete overpacks that provide shielding and ventilation, or in free-standing metal storage casks. Canisters used in concrete shielded storage systems are welded closed.

Welded canisters can be retrieved from storage systems, however, equipment does not exist to open a welded canister in either dry or wet handling. It is impractical to expect a utility to

\footnotetext{
${ }^{5}$ A full-scale demonstration is a test where a dry storage cask/system is loaded with fuel for the purposes of evaluating the effects of dry storage on the fuel contained in that system. These types of tests are intended to be truly prototypic of how fuel is dry stored.

${ }^{6} \mathrm{~A}$ small-scale test is a long-term integrated test intended to simulate the environment of a large storage cask system using no more than one PWR assembly of fuel or two assemblies of BRW fuel.
} 
undertake the assignment to open a welded UNF canister for the purposes of acquiring fuel for UFDC R\&D purposes. The technical and regulatory obstacles to open welded canisters would drive the cost and schedule beyond the projected budget of the UFDC. ${ }^{7}$ The UFDC is investigating the functional requirements for a dry transfer system. An evaluation of the requirements for and a cost estimate of the capability to open welded canisters at a utility is to be completed FY 2014. For now, opening welded canisters to obtain HBU UNF for R\&D is not viable.

The opening of bolted lid storage casks is viable without significant investment in equipment. A bolted lid cask can be placed back in a utility's spent fuel pool and reopened. Rewetting fuel might alter the physical condition of the UNF (e.g. quenching from a high temperature could lead to clad failure or change the surface conditions of the fuel). The UFDC has initiated a study to determine the impact of rewetting on UNF. Those results will be published in FY 2014. If a dry cask can be opened in a utility's pool without adverse effects, this would represent the lowest cost option for recovering HBU UNF from a dry storage system for R\&D purposes.

Bolted lid casks can also be shipped to an offsite facility for opening dry. The INL has performed a viability assessment that concluded large bolted lid storage casks could be handled and opened using an existing facility at the site without significant modifications.[2] The cost estimate included the minor modifications to the facility, and the opening of three storage casks (two already on a storage pad at the INL). At the level of confidence applied to that analysis, the cost for this work ranged from a low of $\$ 9.8 \mathrm{M}$ to $\$ 18 \mathrm{M}$. However, the desired cask would still have to be shipped from a utility's ISFSI.

Shipping a bolted lid cask is possible utilizing existing rail stock. This was done in 2003 when two casks containing UNF from the terminated West Valley Demonstration Project were shipped from western New York to the INL. This shipment was completed in four days using a dedicated train. The casks were NRC licensed for storage and transport. Planning and conduct of the shipment followed the requirements of the DOE Radioactive Material Transportation Practices Manual (460.2-1).

While this shipment was successful, it must be noted the shipment was nearly three years in planning. The shipment involved four railroad companies. Eleven states (more than 22 state agencies), two tribes, and five Federal Railroad Administration regions were involved. A lessons learned document issued in December 2003 documented the complexities of the shipment and made recommendations for improvements/changes that might make future shipments like this easier. ${ }^{8}$ Recommendations included improving how the shipping contracts were established and administered, improving the route and alternative route selection process and working to minimize the impact of a UNF shipment on commercial shipping. Another recommendation was to establish a fixed date for the shipment and not alter that date. Standardization of radiological inspections was recommended along with standardization of mechanical systems testing and other en-route inspections. Better communications and material tracking were recommended.

\footnotetext{
${ }^{7}$ The UFDC operates on an annual budget of \$20-\$25M per year. If an activity would require the investment of a full year's funding $(>\$ 20 \mathrm{M})$, the activity is assumed to be beyond the realm of what is possible for the campaign. While capital requests can be made, the U.S. Congress remains divided on need for and purpose of the UFDC. Thus, larger expenditures are unlikely to be funded.

${ }^{8}$ West Valley Spent Fuel Shipment Project, Lessons Learned, December 2003, marked "for internal use only" by the INL.
} 
Improvements to communication between the DOE and effected states, communities and tribes were recommended. Clearly, moving a storage cask for the purposes of obtaining fuel for UFDC R\&D purposes will be a complex and time consuming process.

Other than the West Valley fuel shipment, actual experience shipping commercial nuclear fuel storage/transport casks by rail is limited. Most of the U.S. experience is by using smaller multi-purpose casks that can be shipped via intermodal/truck/rail transport (e.g. the NAC-LWT cask, the BEA Research Reactor cask, etc.). This is due to the fact that once fuel is loaded into a dry storage system it is licensed to stay at the utility's ISFSI for a minimum of 20 years. Since there is no final disposition pathway, the ISFSI pad is the only destination for UNF. Even fuel from decommissioned reactors continues to be stored at those former reactor sites. Thus, the equipment needed to ship a cask (even if it is licensed for transport) may not exist, or has not been utilized or approved by the NRC for use in the U.S. (e.g. the NAC STC system can be transported in China, but not in the U.S.). Information from other vendors is elusive; it has not be determined if hardware exists in the U.S. to move casks such as the TN-40HT, or TN-68 bolted lid casks.

In the final evaluation, the complexity of shipping a bolted lid storage cask to a dry opening facility for the only purpose of obtaining individual fuel rods or even a full assembly is not viable today. Opening welded canisters for the same purpose is also not viable today. In the future, if a consolidated interim storage site is constructed and is equipped to open these casks/canisters, it may be possible to retrieve individual rods or assemblies at a reasonable cost to the R\&D program. Similarly, if a dry transfer system is developed to support recovery or transfer of UNF from non-transportable casks at a shuttered nuclear installation, that same system might then be used at a reasonable cost for acquiring fuel for R\&D purposes.

\subsubsection{Fuel from the HBU Dry Storage Demonstration Project Cask}

The DOE has contracted with a team lead by EPRI to perform a HBU UNF dry storage demonstration. The project will utilize a TN-32 bolted lid, bare fuel dry storage cask. The EPRI team proposes to relicense the cask for storage and transportation of HBU UNF. Once loaded and the test initiated, the cask will not be opened for at least ten years. The project team desires to demonstrate that the cask can be safely shipped and opened dry. As previously mentioned, the INL has performed an evaluation of how to open that cask dry. The remaining issues involve cask transportation. The project team is evaluating how to open the cask wet if necessary.

An evaluation was conducted by the INL to determine if one of the rail cars, cask transport cradle, and impact limiters from a rail shipment of fuel from the West Valley Demonstration Project might be reused with the TN-32 cask. The West Valley TN-BRP and TN-REG casks are derivatives of the TN-24 design as is the TN-32. It was determined the location of the lifting trunnions was 159.5 inches $(405 \mathrm{~cm})$ between centers for the TN-32 as compared to 106 inches $(269 \mathrm{~cm})$ between centers for the TN-BRP/REG casks. The cask outer diameters and end configurations are also different, precluding the reuse of any impact limiters. Thus, new hardware and equipment must be designed and fabricated to allow rail shipment of the TN-32 cask.

The HBU UNF demonstration cask would be shipped for dry to retrieve samples for R\&D purposes, as well as to perform a complete inspection of the UNF and the cask to confirm the long-term performance of the system. Obtaining fuel for purposes beyond that initial inspection would be secondary to the principal mission of the test and thus, would not bear the full cost of 
transporting and opening the cask. Thus, although many years into the future, this method for obtaining fuel for R\&D purposes would be viable.

\subsubsection{Summary of Fuel Acquisition from Dry Storage Casks}

Acquiring HBU UNF from a large dry storage system is complex and challenging.

- Welded canister systems are the most difficult and cost prohibitive systems from which to acquire fuel. This is due to the fact that there is no equipment or locations to perform this work either dry or wet.

- Bolted lid, bare fuel casks can be opened wet in a utilities spent fuel pool. This is the lowest cost option for acquiring fuel from a full sized storage system. What remains to be determined is whether rewetting the fuel causes undesired changes to the fuel that might preclude its use in the UFDC R\&D program.

- Bolted lid, bare fuel casks can be opened dry by transporting a cask to the INL. This is also an expensive option $(>\$ 10 \mathrm{M})$. If the only purpose were to obtain fuel for R\&D purposes (i.e. a few fuel pins or a single assembly), it would be difficult to justify the expense. On the other hand, if the cask were opened as part of a confirmatory demonstration, the cost to recover fuel samples would be incremental.

- Developing a dry transfer system to obtain R\&D samples of UNF is still being evaluated. However, as with the other options, the cost to develop a semi-portable or fully portable system to open casks for the purposes of gathering a limited quantity of fuel is prohibitive. If such a system is needed to repackage fuel for transport or to replace damaged casks/canisters, then the incremental cost to recover a small quantity of fuel could potentially be justified.

\subsection{UNF from Spent Fuel Pools}

HBU UNF can also be acquired from utility spent fuel pools. This is not without its challenges, but the challenges are less strenuous than those associated with moving full sized storage casks/canisters.

\subsubsection{Sister Pins from the HBU UNF Demonstration}

An early opportunity for the UFDC to obtain samples of HBU UNF is most likely going to come during the EPRI-led full-scale dry storage demonstration. This demonstration will utilize PWR fuel from the North Anna Power Station. These fuel pins serve more than one purpose. They represent the starting condition of the fuel that is being placed in the demonstration cask. This data need will drive the characterization of those sister pins. Once that characterization is complete, some of that material will be available for separate effects and small-scale testing (some will be archived in comparable conditions to dry storage for future reference).

The fuel pins will be selected from locations within the assemblies that will be placed in the demonstration cask, or they may be selected from "sister" assemblies that have similar irradiation histories to those assemblies place in the demonstration cask. The UFDC is evaluating the need to preserve the fuel characteristics of the as-water-stored (pre-drying, also called the $\mathrm{T}_{0}$ condition) fuel pins and also how best to duplicate the drying process to be used for the demonstration cask. Because the cladding characteristics are so important to several data gaps, it is essential to replicate the drying process to ensure the cladding characteristics mimic 
those inside the demonstration cask. Of greatest importance is the ability to match the thermal history of the demonstration cask as closely as possible. This means the heat up rate, dwell time at the peak temperature, and the cool down rate from drying will need to be matched. If these conditions can be matched, post-dried sister pins (also called the $\mathrm{T}_{0}$ ' condition) should have similar hydride content and orientation, and similar mechanical properties to those pins in the demonstration cask.

At this time the fuel assemblies and some of their irradiation history is known for the demonstration. However, the UFDC does not have sufficient information to determine is these pins are sufficiently representative of the general population of PWR HBU UNF to serve all the UFDC R\&D needs for that fuel type.

The effort needed to extract, handle, condition (preparing and drying fuel for transport), and ship the UNF to a National Laboratory will be observed closely. The complexity of the operations and the associated cost will be tracked to help assess the value and/or desire to acquire more fuel from either the same utility or another utility.

\subsubsection{BWR HBU UNF}

The full-scale demonstration focuses on the performance of PWR fuel during dry storage. This is because of a general belief that PWR fuel performance will bound BWR performance. PWR fuel typically has thinner cladding than BWR fuel. PWR fuel typically has a higher internal temperature than BWR fuel during operation and PWR fuel is presently taken to higher burnups than BWR fuels.

BWR fuels have some characteristics not found in PWR fuels. Hydrides can accumulate under oxide and CRUD ${ }^{9}$ formations to form hydride "lenses." Thinner BWR fuel clad designs are becoming the norm for 10x10 assemblies. It is known that the mechanical properties of fuel clad are heavily influenced by hydride formation and orientation and also radiation damage/hardening. It is unknown what effect thermal annealing of radiation damage will have on the mechanical properties of fuel clad. There is a possibility that BWR fuel clad, postannealed, may not be bounded by PWR fuel clad in a post-annealed condition. Thus, it will be important to obtain some HBU BWR fuel pins for the UFDC R\&D program. Since no BWR fuel is included in the full-scale demo, it has been proposed to obtain two 10x10 HBU BWR assemblies for inclusion into a long-term small-scale test that would parallel the PWR-based fullscale demonstration.

Table 2.1 shows there are seven plants that have discharged HBU BWR UNF. It is known that Duke Energy's Brunswick Nuclear Plant is using an AREVA Atrium 10XM 10x10 fuel design. This fuel has zircaloy-2 cladding and is available with or without an iron-enhanced liner. This would be a good candidate fuel for inclusion in SETs and a SST. The fuel type used in each of the other six reactors shown in Table 2.1 is not known at this time.

\subsubsection{PWR HBU UNF}

Additional PWR HBU UNF may be required for the testing program. While the full-scale demonstration will provide fuel pins that can be used for $\mathrm{R} \& \mathrm{D}$, those pins will not be available

\footnotetext{
${ }^{9}$ CRUD, Corrosion Residual Unidentified Deposits is a term used to describe oxides consisting of iron, nickel, cobalt, etc. that can be in the form of spinels.
} 
for several years. To support ongoing efforts, it is necessary to look for additional sources of PWR HBU UNF for SETs and SSTs.

Because the full-scale demonstration will not be opened for at least ten years, it is desirable to have fuel in other tests that can be monitored more easily and are more accessible to take samples. For example, if radiation damage annealing is an important mechanism, it will be useful to take samples from the fuel as it anneals to determine the extent of annealing. While this can be done on fuel clad samples, there is benefit to determining the properties of the integrated fuel/clad system as represented by the small-scale test.

\subsection{Fuel Recommendations for Acquisition}

\subsubsection{Data Gaps}

As mentioned in Section 1.0, there are several identified several data gaps for which data from UNF samples can provide useful information. Again, these gaps are:

- Subcriticality (burnup credit and moderator exclusion) - radionuclide inventory in fuel rods

- Stress profiles - mechanical strength of the fuel rod

- Fuel Transfer Options - ensure fuel is handled in a prototypic manner

- Cladding - annealing of radiation damage

- Cladding $-\mathrm{H}_{2}$ effects, reorientation and embrittlement

- Cladding $-\mathrm{H}_{2}$ effects, delayed hydride cracking

- Cladding - oxidation

- Cladding - creep

- Fuel Assembly Hardware - stress corrosion cracking (SCC) of lifting hardware and spacer grids

The report, Gap Prioritization and Closure Plan[6] provides recommendations for the types of testing that may close the gaps. A summary of these data types are below:

- Subcriticality (burnup credit and moderator exclusion). Radiochemical assays of fuel pins are recommended along with reactor operational history data. HBU fuel can be analyzed by any of the national laboratory's radiochemical labs. The challenge is to get the reactor operational history. Utilities consider this data part of their competitive advantage, and are reluctant to release that information. Efforts to revive the requirement for utilities to fill out the Nuclear Fuels Data Survey, Form RW-859, met strong resistance to providing this additional data and the request was withdrawn. However, efforts by ORNL to gather this data have been more fruitful in FY 2013. This information request becomes an item for consideration when selecting a utility from which to acquire fuel.

- Stress Profiles. The testing recommended for this cross-cutting data gap include vibration testing of fuel assemblies and potentially individual fuel pins. If a full fuel assembly is acquired, it may be useful to instrument the shipping cask and truck trailer. Applying instruments (i.e. strain gages) to the fuel is difficult and likely could not be done in the fuel pool prior to loading (attempting to perform a complex operation in a highly regulated work space). 
- Cladding. The most important cladding information to be obtained is the mechanical properties at different times. These mechanical properties will vary based on cladding type, burnup, oxide and crud layer thicknesses, hydride quantity and orientation, radiation damage and annealing, and temperature. Mechanical properties data will be obtained from ring compression tests, expanded plug tests, burst tests, 3- and 4-point bend tests, and creep tests, in addition to traditional hardness, impact, and tensile strength tests. Testing will involve both SETs and potentially a SST. Characteristics to be evaluated include annealing of radiation damage, hydride reorientation and embrittlement, delayed hydride cracking, clad oxidation, and cladding creep.

Characterizing these effects will require the largest sample set. It may not be sufficient to simply request fuel that has a certain cladding and fuel burnup. While the burnup has become a generalized expression that is used to infer that a fuel with a high burnup has experienced more operational stress than a low burnup fuel. However, there is another metric, "fuel duty," that captures estimates of fuel clad corrosion, hydrogen pickup, temperature history and is more descriptive of the clad condition as opposed to the fuel pellet burnup. [3] It will be important to gather information on proposed fuels to be acquired so the fuel duty can be calculated. This can be done by a utility or by the UFDC (EPRI methods that are used are described in [3]). The higher the fuel duty, the higher the clad corrosion and fission gas release. It would be useful to acquire fuel pins with a range of fuel duty values, however, if that is not possible, then acquiring fuel pins with high fuel duty values may be desirable to bound the worst case conditions of the fuel.

- Fuel Assembly Hardware. In general, irradiated fuel assembly hardware will not be available to the UFDC. However, if a full assembly of fuel is acquired for testing and placed in a SST, then grid spacers and end plates can be subjected to testing. Even then, the testing will be limited to a single alloy. Different fuel vendors use different materials for hardware (zircaloy, Inconel, stainless steel).

\subsubsection{BWR HBU Recommendations}

Identification of the exact fuel type and configuration is not easily determined. A review of the RW-859 database does not fully list what fuel is used in some of the reactors as it was last updated in 2002. It was possible to determine that Duke Energy is using AREVA Atrium 10XM fuel at the Brunswick Nuclear Plant, but the other reactors were not so easily determined. An activity has been initiated to contact each utility's fuel groups and inquire what fuel they have discharged.

Data gaps regarding cladding characteristics will be most sensitive to the types of fuel acquired. To bound the worst case conditions, fuels should have both high burnup and high fuel duty values. BWR fuel configured in 10x10 assemblies burned above $50 \mathrm{GWD} / \mathrm{MTU}$ is expected to have high fuel duty values. 10x10 assembly fuel has thinner clad than a 7x7 or even a 9x9 configuration. The majority of these fuels have a burnable poison incorporated into the fuel matrix, but this should not be important to the mechanical properties of the fuel pin or fuel clad. These fuels also have zircaloy liners that may be have iron additions. This is becoming a common practice as burnups are increased, so any BWR HBU fuel acquired should have a cladding liner to be consistent with industry practice.

The quantity of fuel to be acquired should include several pins (4-8) for SETs, and one to two full assemblies for a SST. The majority of BWR reactors in the U.S. are of the General Electric 
BWR/4-6 assembly class and all but one of the reactors listed in Table 2.1 are of this class (Dresden is a BWR/2-3 class), so it is not expected that reactor type will have a significant influence on properties.

\subsubsection{PWR HBU Recommendations}

Table 2.2 shows 17 reactors that have discharged fuel above 50 GWD/MTU burnup. These reactors have four basic fuel designs ranging from 14x14 configurations to the Westinghouse $17 \times 17$ fuel design. The Westinghouse design is the most common. PWR fuel cladding varies by fuel vendor, zircaloy-4 (multiple vendors), ZIRLO (Westinghouse), and M5 (AREVA). As with the BWR fuels, to bound the properties of PWR HBU UNF, fuel with burnup above 50 GWD/MTU and high fuel duty values should be sought.

There is a need for PWR fuel for SETs. The full-scale demonstration is one test platform for testing PWR assemblies, but due to the utility's restrictions on potential impacts to the plant, no monitoring of the demonstration will occur other than temperature monitoring. A SST would be a useful complement to the full scale demo and would allow more access to PWR HBU fuel pins as they age under dry storage conditions.

The full-scale demonstration will provide up to 25 pins of PWR HBU UNF to the UFDC for characterization and R\&D. Because the supply of HBU fuel for the full-scale demonstration is limited (about 37 total assemblies to select from) the fuel duty of the pins may not be as high as can be found elsewhere. It is recommended the UFDC acquire several (4-8) pins from other utilities in addition to the full-scale demonstration sister pins. A full assembly of PWR HBU UNF should be acquired to support a SST operated in parallel to the full-scale demonstration.

\section{FUEL SHIPMENT TO INL}

\subsection{Rail or Truck Shipping}

As described in Sections 3.2, rail shipments, as analyzed for moving full size dry storage casks, are not viable due to the complexity and high cost for acquisition of small quantities of fuel pins for R\&D purposes. If the cask were being moved for other purposes (e.g. demonstration of shipping, inspection of the entire cask contents, continuing a demonstration program), then the cost might be justified.

Truck shipments have been used routinely for several decades to move up to assembly quantities of UNF. Today, these shipping casks have external packaging that allows them to be shipped by truck, rail, ship, and even by airfreight in the U.S. and internationally.

One vendor of shipping casks is NAC International, Inc. that maintains a fleet of eight NACLWT shipping casks. Soon (estimated in 2014), Transnuclear, Inc. will enter the shipping cask market with a new cask, the TN-Long Cask (TN-LC). Both casks have similarities and differences that may impact their use.

\subsection{Transport Casks}

\subsubsection{NAC-LWT}

The NAC International Inc., NAC-LWT shipping cask is only one truck transport cask available in the U.S. at this time. The NAC-LWT is a steel-encased, lead-shielded Legal Weight Truck transportation cask. The cask is authorized for transporting several types of UNF, including one PWR or two BWR assemblies. Full assemblies of HBU UNF are not presently 
allowed for shipping in this cask due to the potential for a high heat load involving short cooled fuel (e.g. fuel that has been recently discharged with little cooling such that the heat load would be $>2.3 \mathrm{~kW}$ ). However, up to 25 pins of PWR or BWR HBU UNF can be shipped with a burnup up to $80 \mathrm{GWD} / \mathrm{MTU}$ and cooling times as short as 150 days (keeping under the $2.3 \mathrm{~kW}$ for PWR or $2.1 \mathrm{~kW}$ for BWR fuels). A special fuel pin holder and basket are used for this purpose. The fuel holder array will accommodate fuel pins up to 165 inches $(419 \mathrm{~cm})$ in length.[4]

To ship a single assembly of PWR or two assemblies of BWR HBU UNF, the Certificate of Compliance $(\mathrm{CoC})$ would need to be modified and approved by the NRC. The heat load for the cask would still be limited to about $2.3 \mathrm{~kW}$. A preliminary estimate suggests that for a PWR assembly with $55 \mathrm{GWD} / \mathrm{MTU}$ assembly average burnup, the assembly would need to be stored in pool about 5 to 6 years. This would allow the heat limit for the cask to be met. The radiation shielding for the cask is expected to be adequate.

\subsubsection{TN-LC}

Transnuclear, Inc. (TN) is preparing to bring the TN-LC to market in the first quarter of calendar year 2014. This cask received a CoC in December 2012. The packaging, designed for transport of irradiated test, research, and commercial reactor fuel, consists of a payload basket, a shielded body, a shielded closure lid and top and bottom impact limiters. The packaging body is a right circular cylinder, composed of top and bottom end flange forgings connected by inner and outer shells. Lead shielding, is placed between the two cylindrical shells, in the bottom end assembly, and in the lid. The cask will accommodate either one PWR assembly or one BWR assembly. The cask will have a heat load limit of $3.0 \mathrm{~kW}$ per PWR assembly and $2.0 \mathrm{~kW}$ per BWR assembly. The fuel baskets will accommodate fuel up to 14 feet $(427 \mathrm{~cm})$ in length.[5]

Rather than distinguish between low burnup and high burnup, the CoC contains tables from which one can determine if the fuel can be shipped or not. The tables list burnup on the vertical axis (from 10 to 62 GDW/MTU), and fuel enrichment on the horizontal axis (wt $\%$ U-235 from 0.7 to 5.0). A PWR fuel assembly with initial enrichment of $4.2 \mathrm{wt} \% \mathrm{U}-235$ and a burnup of 55 GWD/MTU will require cooling for a minimum of 5.85 years prior to shipping.

The cask will also have fuel pin holders for either 9 or 25 pins. Fewer pins reduces the cooling time substantially. For example, for the PWR fuel example in the previous paragraph, 25 pins would need to cool about 110 days and for 9 pins the fuel would need to cool about 92 days.

To ship fuel using this cask, the first user at any receiving laboratory will need to develop handling procedures, fixtures, tooling, and perform readiness activities for that first use.

\subsubsection{Shipping Cask Summary}

Both manufacturer's shipping casks have similar payload capacity but there are subtle differences between the two:

- INL, ORNL, and Pacific Northwest National Laboratory (PNNL) have handled the NAC-LWT. To receive HBU UNF, a receiving laboratory would need to ensure they are prepared to handle the HBU 25-pin fuel holder array, ensure their facility safety limits are adequate, and some level of management assessment would need to be performed to ensure operational readiness.

- No laboratory has had the opportunity to handle the TN-LC cask as it is not yet to 
market. Every laboratory will have to develop new procedures, tooling, and fixtures to handle this cask. Operation readiness will be more rigorous for the first usage. Once these efforts have been completed, the cost for handling this cask should be similar to the NAC-LWT

- The NAC-LWT is not certified to ship full assemblies of HBU UNF. This would require a modification to the $\mathrm{CoC}$ for the cask.

- The TN-LC is certified to ship full assemblies of HBU UNF.

- Both casks are certified for shipments of 25 or less pins of HBU UNF.

To ship 25 or fewer HBU UNF pins, using the NAC-LWT would avoid "first user" cost associated with the new TN-LC. Shipping full assemblies of HBU UNF with the NAC-LWT will require a $\mathrm{CoC}$ revision, while the using the TN-LC could cause the user to incur the "first user" costs. The use of either will come down to availability, program need, cost, and schedule requirements.

\subsubsection{Receiving Shipping Casks}

The INL is capable of receiving shipping casks in two locations; the Hot Fuels Examination Facility (HFEF) at the Materials and Fuels Complex, and at the CPP-603, Irradiated Spent Fuel Storage Facility, at the Idaho Nuclear Technology and Engineering Center (INTEC). Both facilities have loaded and unloaded payloads from the NAC-LWT shipping cask. However, neither facility has handled the 25-pin HBU fuel holder array.

To handle the array, a new strategy for unloading the NAC-LWT would need to be developed for HFEF. Traditionally, fuel baskets weigh less than $700 \mathrm{lbs}(318 \mathrm{~kg})$ and the HFEF main cell electro-mechanical manipulator is used in conjunction with the main hot cell crane to remove the fuel basket from the cask. The 25-pin array weighs nearly $800 \mathrm{lbs}(364 \mathrm{~kg})$ which exceeds the load limit for the electro-mechanical manipulator. A conceptual, two-step process utilizing the hot cell crane has been proposed. A holder would need to be developed that could support the 25-pin array as it is lifted up into the hot cell. A grapple would be fitted to the crane hook to reach down through the floor of the hot cell and into the cask. The grapple would connect to the top of the fuel basket which would be lifted up into the hot cell where the holder would allow the crane to be repositioned. The repositioning is required as the grapple assembly is about 6 feet long $(183 \mathrm{~cm})$ and there is insufficient head room to lift the fuel basket all the way up into the hot cell. Once the grapple is replaced with a shorter grapple, the basket can be pulled up into the hotcell.

Unloading of the fuel basket would be done at the window 9M pit. This operation was developed for other Lead Test Assemblies and works very well. Once the fuel basket is open, individual fuel pin holders can be attached to each fuel pin and the fuel pins can be removed from the 25-pin array. The fuel pins would be placed either in the HFEF LTA fuel basket for protection when the fuel pins are not being examined or just for storage. Additional fuel pin protective holders have been proposed if there is a need to protect individual pins separately from each other.

Another way to open the cask is to use the CPP-603 facility at INTEC. This facility requires fewer tooling modifications to handle the cask with the 25-pin array. The two-story fuel handling cave allows the operator to look down on top of the cask for all operations. The cask lid can be removed and the fuel basket extracted using the crane. The basket top can be removed while still in the cask, and the 25-pin array can be removed and placed in an in-cell storage well. 
The individual fuel pin holders can be attached to each pin and they can be removed from the 25pin array. The pins can then be placed in protective holders.

Up to 9 pins could then be sent to HFEF using a TN-FSV shipping cask utilizing the INL haul road. The TN-FSV is smaller than the NAC-LWT and has been handled in the HFEF. By delivering fewer fuel pins at one time to HFEF, the weight limit restriction of the electromechanical manipulator is avoided which allows for easier operations.

The UFDC will evaluate both of these options as part of FY 2014 activities to prepare for receipt of fuel pins. It was not within the FY 2013 UFDC scope to have these strategies completely developed beyond conceptual design.

Evaluation for handling of the TN-LC cask has not been initiated. This is because there are no casks available to neither evaluate, nor have blueprints or other information been made available to the UFDC that would allow development of conceptual designs. Because this cask will be different that previous casks handled at the INL, it is expected that little of our existing cask handling equipment will work with this cask. As cask information becomes available, the campaign can evaluate the feasibility of using this cask.

It must also be noted that receiving a full assembly of PWR fuel at the INL will require permission from the State of Idaho as those assemblies contain more than $400 \mathrm{~kg}$ heavy metal ( $\sim 85 \mathrm{~kg} /$ assembly). The State has granted permission for research quantities of materials up to $400 \mathrm{~kg}$ to be brought into the State for R\&D purposes, so such a shipment would require their permission.

\section{CONCLUSIONS}

The UFDC will need to acquire HBU UNF to close data gaps important to the development of the technical bases to support the continued safe and secure storage of UNF for extended periods, subsequent retrieval, and transportation.

In developing this report it was determined that it is not viable to ship a full sized dry storage system to the INL (or any laboratory) for the purposes of recovering fuel for R\&D purposes.

Acquiring fuel from reactor spent fuel pools is viable and there are shipping casks available for moving fuel from pools to laboratories for R\&D purposes. Shipping 25 or fewer HBU UNF fuel pins to a laboratory can be done using the NAC-LWT cask. Minor investments will be needed to handle the 25-pin fuel array (hot cell fixturing to hold the basket for opening and procedures to do so). This would be required at any laboratory as no lab has handled this basket before. The INL has two facilities that can handle the NAC-LWT cask (HFEF and CPP-603).

It will take investment to move a full assembly of PWR or BWR HBU UNF from a pool to a laboratory because the NAC-LWT is not certified for full assemblies of HBU fuel, and the TNLC does not yet exist. Handling a PWR-type assembly has been performed at the INL at HFEF about 13 years ago (the TP-BAR LTA used to demonstrate tritium production in a light water reactor). Therefore, no major investments are needed to handle an assembly of fuel at the INL.

The TN-LC could become a viable cask to use for shipping assemblies or small quantities of UNF. However, the first users of that cask will incur all the costs to develop the tools, training, procedures, and complete the readiness to receive that cask. 
Fuels recommended to be acquired include HBU PWR and BWR UNF. For both fuel types, it is desired to not only acquire fuel with as high a burnup as possible (above $50 \mathrm{GWD} / \mathrm{MTU}$ ), but to also determine the fuel duty and select fuels with high fuel duty values if at all possible. This will help bound the inventory of fuel that exists today by providing fuel with the most irradiation damage and most operational stress on the cladding. Fuel should be acquired from the most common fuel designs to ensure the data obtained is applicable to the majority of the inventory in the U.S. fleet today.

\section{REFERENCES}

1. "Used Fuel Disposition Campaign - Gap Analysis to Support Extended Storage of Used Nuclear Fuel," Revision 0, FCRD-USED-2011-000136 (PNNL-20509), Pacific Northwest National Laboratory, January 31, 2012

2. "Viability of Existing INL Facilities for Dry Storage Cask Handling," Revision 1, FCRDUFD-2013-00027, INL/EXT-13-29035. Idaho National Laboratory, April 30, 2013

3. “Used Nuclear Fuel Characteristics at End of Life," Revision 0, FCRD-UFD-2013-000130, March, 2013

4. U.S. Nuclear Regulatory Commission Certificate of Compliance, certificate number 9225, NAC International Inc. NAC-LWT package. Available from: http://rampac.energy.gov/certinfo/certificates/nrc/default.aspx

5. U.S. Nuclear Regulatory Commission Certificate of Compliance, certificate number 9358, Transnuclear, Inc. TN-LC package. Available from: http://rampac.energy.gov/certinfo/certificates/nrc/default.aspx

6. Used Fuel Disposition Campaign - Gap Prioritization and Closure Plan," Draft, FCRDUSED-2012-000109, Pacific Northwest National Laboratory, April 30, 2012 